\title{
The effects of conservation land to provide feed in dry land farming on the East Island Indonesia
}

\author{
Helena da Silva ${ }^{1, *}$, Yohanes L. Seran ${ }^{1}$, Noldy R E Kotta ${ }^{1}$ and Moh. Saeri ${ }^{2, *}$ \\ ${ }^{1}$ Assessment Institute for Agricultural Technology East Nusa Tenggara, Indonesia \\ ${ }^{2}$ Assessment Institute for Agricultural Technology East Java, Indonesia
}

\begin{abstract}
The study was conducted in South Central Timor and North Central Timor in the month of March to May 2017, the aims are the determinate the additional amount of money value of feed crops planted as a hedge row in vegetative conservation than without conservation, and the value of money of corn plants grown in the hedge row cultivation land for five years. Data were collected through interviews and field observations. The results showed that: (a) Production of biomass feed is grown as a hedge row to increase over time utilization and production will be stable after the fourth year by $25 \mathrm{t} \mathrm{ha}^{-1}$ year $^{-1}$, (b) The relationship between biomass production and utilization of time to form a linear line with equation $y=6032.63 \mathrm{x}-592.6$. (c) The relationship between biomass with time concession revenue line shape with the linear equation $\mathrm{Y}=$ $2,021,458.37 x-2,444,254.57$, (d) Hedge row has the potential to supply cattle feed about 2-3/6 months fattening or 4-6 fish/year, (e) Gross margin vegetative conservation concession for five years at IDR 50,111,138 ha and without conservation of IDR 20,077,617
\end{abstract}

\section{Introduction}

The cause of the decline in national food production that is felt today is increasingly narrow area of productive agricultural land (especially on the island of Java) as a result of function shifts such as conversion of rice fields, in addition to the global issue of increasing land degradation (in developing countries). One of alternative which is expected to increase the potential of plant production in order to meet food needs is the utilization of dry land. Apart from the fact that there are quite a lot of areas available, some of the dry land has not been managed optimally, so that it allows opportunities for its development.

The development of the population of Timor Island is increasing day by day, causing the need for more food with better variety and quality to increase. Current Conditions, the number of population in Timor Island is 2.37 people [1] or $44.45 \%$ of the total population of NTT [1]. The challenges in the future will be even more severe because the consequences of population growth can have an impact on the conversion of land from agriculture to housing, industry and other uses, whereas currently East Nusa Tenggara Province still needs to import 3,252 tons of grain, especially rice per year [1] .

\footnotetext{
*Corresponding authors: helena dasilva73@yahoo.com, saerimoh@yahoo.com
} 
The policy of developing dry land, which mostly has slopes $>15 \%$, needs to consider the multi-functions of agriculture and the environment. Development policies which is impartial to agriculture will disrupt the stability of food security, even worsen the quality of environment, and have a negative impact on economic, social and political stability [2]. For the sustainability of life and ensuring their welfare, it is impossible for humans to ignore efforts to prevent the degradation of various land functions.

The condition of the agricultural system on Timor Island is dominated by field agriculture. Farmers cultivate food crops and annual crops with mixed cropping patterns. The use of dry land by farmers is still in the subsistence level and productivity is low [2] and does not pay much attention to soil conservation, so the possibility of soil erosion is high [3]. Apart from farming, farmers also raise livestock which is an important component of the farmers' income. [4] stated that livestock in NTT, especially in Timor Island, is dominated by Bali cattle, and in the last 30 years NTT has become the largest livestock producer. Livestock contributes significantly to household income, around 15$50 \%$ of farmers' income.

During the system of management, agriculture is as one form of soil conservation that integrates plant components and livestock components in one plot of land is the alley cropping pattern. The application of the alley cropping pattern is one of alternative to support the development of a sustainable agricultural system. Utilization of technology in the implementation of development needs to serve the creation of as many job opportunities as possible and increase productivity and utilize as many tools as possible to help achieve development goals [5].

Several results of research related to conservation measures through vegetative means, as reported [6]. [7] stated that alley cropping can reduce the rate of soil erosion by 0.68 tons/ha/year and runoff by $1.43 \mathrm{~m} 3 /$ ha/year in the sixth season of planting with corn production $0.82 \mathrm{ton} / \mathrm{ha}$. [8] added that the ability of alley cultivation to reduce the rate of erosion and runoff is proven to be lower than the agroforestry planting system.

This study aims to determine (a) the additional income generated by fodder crops planted as hedges in vegetative conservation compared to land without conservation efforts, (b) the amount of money generated by corn plants planted among hedgerows in vegetative conservation as compared to animal husbandry where no conservation measures are applied.

\section{Methodology}

Location of the research is conducted in two regencies involving 3 (three) villages in 2 (two) regencies, namely Timor Tengah Selatan (TTS) and Timor Tengah Utara (TTU), taken place during March to May 2017. The method of research used is a survey method that compares economic values of 2 types of land management, namely land where vegetative conservation efforts are carried out and land that is not carried out for 5 years of land management. The values which compared are feed biomass production and corn production.

\subsection{Data Collection}

Data collected includes:

1. Data on feed biomass production was collected through direct observations and measurements in the field;

2. The price of biomass is determined based on the willingness to pay by local farmers;

3. Labor costs for setting up hedge rows collected through semi-structured interviews; 
4. Harvest costs for hedge row crops were collected through semi-structured interviews with garden owners, including labor costs for harvesting hedge row for 1 year;

5. Material requirements for the manufacture of hedge rows were collected through observation and semi-structured interviews, including: the number of polls (one clump) used for the manufacture of hedge rows and the price of polls.

The economic value of forage plant biomass grown as hedge row is calculated from the amount of feed biomass production that can be harvested in 1 hectare for one year multiplied by the value of the biomass minus labor and material costs.

\subsection{Analysis Data}

The relationship between years of land use and total income was analyzed by linear or nonlinear regression. The equations of these models according to [9] are shown in Table 1.

Table 1. Models of Linear and Non-Linear Regression Equations

\begin{tabular}{|l|l|l|}
\hline \multicolumn{1}{|c|}{ Models } & \multicolumn{1}{|c|}{ Transformation Models } & \multicolumn{1}{c|}{ Equation Models } \\
\hline Linier & $Y=b_{o} \pm b_{1} x$ & - \\
\hline (logarithmic) & $Y=b_{o} \pm b_{1} \ln (x)$ & - \\
\hline (invers) & $Y=b_{o} \pm b_{1} / x$ & - \\
\hline (quadratic) & $Y=b_{o} \pm b_{1} x \pm b_{2} x^{2}$ & - \\
\hline (cubic) & $Y=b_{o} \pm b_{1} x^{2} \pm b_{2} x^{3}$ & - \\
\hline (compound) & $Y=b_{o} b_{1}^{x}$ & $\ln (Y)=\ln \left(b_{o}\right) \pm \ln \left(b_{1}\right) x$ \\
\hline (power) & $Y=b_{o} x^{b 1}$ & $\ln (Y)=\ln \left(b_{o}\right) \pm b_{1} \ln (x)$ \\
\hline S (sigmoid) & $Y=e^{b o \pm b 1 / x}$ & $\ln (Y)=b_{o} \pm b_{1} / x$ \\
\hline (growth) & $Y=e^{b o \pm b 1 x}$ & $\ln (Y)=b_{o} \pm b_{1} x$ \\
\hline (exponential) & $Y=b_{o} e^{b 1 x}$ & $\ln (Y)=\ln \left(b_{o}\right) \pm b_{1} x$ \\
\hline
\end{tabular}

Information:

$\mathrm{Y} \quad=$ income

bo $\quad=$ constant

$\mathrm{b} 1 \quad=$ regression coefficient

$\mathrm{x} \quad=$ year of land use

\subsection{Data Analysis}

To compare the income and costs between vegetative conservation land and non-conserved land per year, a Gross Margin analysis was carried out. According to [10] Gross Margin is revenue minus variable costs calculated by the formula: Gross Margin =Revenue - Variable cost

The total economic value of vegetative conservation is calculated by the formula:

$\mathrm{NET}=\mathrm{x} 1+\mathrm{x} 2$; NET: Total economic value; X1 : economic value of feed biomass production grown as hedge row.; X2 : economic value of corn planted between hedge rows.

The costs calculated for the land being conserved are labor costs for making hedge rows, maintenance costs for hedge rows, material costs for making hedge rows, and costs for farming corn planted between hedge rows. Meanwhile, the revenue that is calculated for land that is not being conserved is revenue from corn farming. The costs calculated for land that are not being conserved are costs for corn farming. 


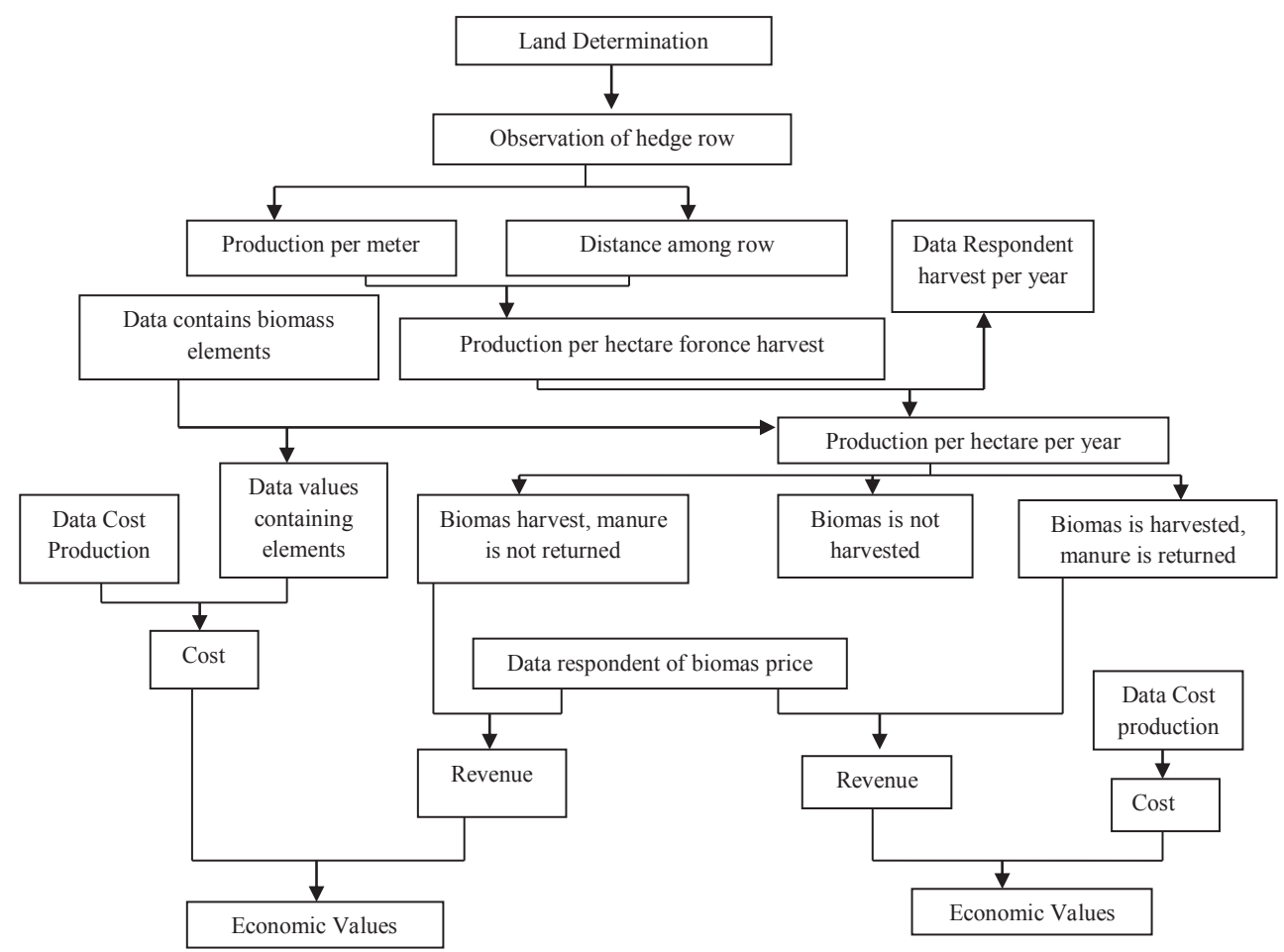

Fig. 1. Flow Chart of Economic Values Calculation of Biomass Hedge Row 


\section{Results and Discussion}

\subsection{Conservation Impact on Hedge Row Biomass Production}

There are differences in how to plant hedge row plants at the three observation locations. Vegetative conservation is commonly planted by farmers in North Mollo Sub district, TTS Regency that is elephant grass ( Pennisetum purpureum ) planted together with corn in the first year, while farmers in West Miomafo Subdistrict, TTU Regency usually plant calliandra (Calliandra calothyrsus), as animal feed. Where Farmers in North Mollo District usually plant elephant grass together with planting corn in the first year of exploitation by cuttings. Unlike farmers in West Miomafo District, calliandra seed planting is carried out in the second year. The planting of fodder crops is usually done in stages in different years.

The results showed that $82 \%$ of the farmers owned cattle, with a range of ownership of 1 - 6 heads of household ${ }^{-1}$ and an average of 1.86 heads of households. The results of the t-test of cattle ownership between land owners who carried out vegetative conservation and those who did not conserve were not significantly different. This situation means that there is no relationship between cattle ownership and vegetative conservation measures. For information, farmers who do not implement vegetative conservation do not mean that they do not have cows, but usually have more than 1 plot of land and one of them is planted with forage crops, either planted as a hedge row or planted on the edge of the garden, yard or part of the garden with steep slopes.

Elephant grass can be harvested 2-4 months after planting, while calliandra is a tree legume, so the harvest can only be harvested after the second year. Farmers usually take feed biomass in stages. Harvesting is usually done 3-4 times per week with a weight of 20-30 kg per harvest, and this biomass can only be harvested 5-7 times per year. This feed intake also only relies on family labor. Biomass that is taken for cattle feed, but the manure is not returned to the field, but for vegetable fertilizer on separate land, is sold or not used.

The results of the observation that the wet biomass weight per meter in the row increased with the age of the plant. Production will be stable after the fourth year of exploitation with production reaching 25 tons ha year.

If the biomass is valued in money as revenue, that is, it is valued at IDR 625 per $\mathrm{kg}$ of wet biomass. The need for elephant grass seeds is calculated by the distance between rows of 7.85 meters and the distance between plants $15 \mathrm{~cm}$, the seed needs are 9443 cuttings, and the price of seeds is IDR 100 per cutting, the cost of elephant grass seeds is IDR 944,300. Meanwhile, calliandra needs $10 \mathrm{~kg}$ of seeds per hectare at a price of IDR 60,000 per kg. Planting and harvesting labor costs are valued at IDR 50,000 per HOK. The cost of loss of nutrients contained in the biomass is assessed by the conversion of dry biomass $2 \% \mathrm{~N}, 0.25 \% \mathrm{P}_{2} \mathrm{O}_{5}$, and $4 \% \mathrm{~K}_{2} \mathrm{O}$ [11], so the total income of farmers from vegetative conservation is IDR $59,473,125$ ha $^{-}$

${ }^{1}$ (Tables 2, 3 and 4). 
Table 2. Income derived from the production of Biomass Hedge Row on Vegetative Conservation

\begin{tabular}{|c|c|c|c|r|c|}
\hline $\begin{array}{c}\text { The year } \\
\text { of } \\
\text { operation }\end{array}$ & $\begin{array}{c}\text { Wet } \\
\text { biomass } \\
\text { production } \\
\text { per m (kg) }\end{array}$ & $\begin{array}{c}\text { Distance } \\
\text { between } \\
\text { rows (m) }\end{array}$ & $\begin{array}{c}\text { Harvest } \\
\text { frequency } \\
\text { per year } \\
\text { (times) }\end{array}$ & $\begin{array}{c}\text { Wet biomass } \\
\text { production } \\
\text { (kg/ha/year) }\end{array}$ & $\begin{array}{c}\text { Biomass } \\
\text { revenue } \\
\text { (IDR) }\end{array}$ \\
\hline 1 & 1.59 & 10.55 & 4 & 8,774 & $5,483,750$ \\
\hline 2 & 2.46 & 10.55 & 5 & 14,117 & $8,823,125$ \\
\hline 3 & 1.8 & 9.86 & 5.6 & 17,353 & $10,845,625$ \\
\hline 4 & 7.43 & 6.73 & 4.51 & 28,391 & $17,744,375$ \\
\hline 5 & 6.21 & 8.13 & 4.89 & 26,522 & $16,576,250$ \\
\hline
\end{tabular}

Remark: * calculated based on biomass price is IDR $625 / \mathrm{kg}$

Table 3. Cost of Hedge Row Plant Seeds/Seeds on Vegetative Conservation

\begin{tabular}{|c|r|r|r|r|r|r|r|}
\hline \multirow{2}{*}{$\begin{array}{c}\text { Year of } \\
\text { operation }\end{array}$} & \multicolumn{2}{|c|}{$\begin{array}{c}\text { Cost of } \\
\text { seeds/seeds }\end{array}$} & \multicolumn{2}{|c|}{$\begin{array}{c}\text { Planting costs } \\
\text { (HOK) }\end{array}$} & \multicolumn{2}{|c|}{$\begin{array}{c}\text { Harvest costs } \\
\text { (HOK) }\end{array}$} & $\begin{array}{c}\text { Total cost } \\
\text { of seeds } \\
\text { + labor }\end{array}$ \\
\cline { 2 - 8 } & Physical & $\begin{array}{c}\text { Value } \\
\text { (IDR) }\end{array}$ & Physical & $\begin{array}{c}\text { Value } \\
\text { (IDR) }\end{array}$ & Physical & $\begin{array}{c}\text { Value } \\
\text { (IDR) }\end{array}$ & \\
\hline 1 & $6,161 *$ & 616,100 & 10 & 500,000 & 125 & $6,250,000$ & $7,366,100$ \\
\hline 2 & $2.33^{* *}$ & 139,800 & 7 & 350,000 & 125 & $6,250,000$ & $6,739,800$ \\
\hline 3 & 0 & 0 & 0 & 0 & 175 & $8,750,000$ & $8,750,000$ \\
\hline 4 & 0 & 0 & 0 & 0 & 173 & $8,650,000$ & $8,650,000$ \\
\hline 5 & 0 & 0 & 0 & 0 & 182 & $9,100,000$ & $9,100,000$ \\
\hline
\end{tabular}

*) Elephant grass commodity. Calculated the distance between rows (cuttings)

**) Calliandra commodity. Need of Seeds $(\mathrm{Kg})$

The results of the study [3] showed that the group that applied the conservation method had as many as 20 cows in the cage. Cattle are kept in cages so that manure can be collected to produce biogas and compost. This type of semi-permanent cage with a capacity for 20 to 24 cattle. Each group member also own 2 - 4 cows. Cattle belonging to group members are grazed on agricultural land. The results of the study [12] also show that the cattle business developed by group members, although it has been caged, is still traditional and is developed on a part-time basis.

The results of the study [8] stated that the type of elephant grass contains $10 \%$ crude protein and $31 \%$ crude fiber. Elephant grass is highly favored by breeders because of its greater production compared to other types of forage grass. This grass also has a relatively fast harvest age and an easy planting process, so many breeders choose to cultivate this elephant grass to be used as animal feed. 
Table 4. Cost Analysis of Nutrient Loss from Feed Biomass on Vegetative Conservation

\begin{tabular}{|c|c|c|c|c|c|c|c|c|}
\hline $\begin{array}{c}\text { Year of } \\
\text { operation }\end{array}$ & $\begin{array}{c}\text { Dry biomass } \\
\text { production } \\
(25 \% \\
\text { conversion of } \\
\text { wet biomass) } \\
\text { (kg/ha/year) }\end{array}$ & $\begin{array}{c}\mathrm{N} \text { content in dry } \\
\text { biomass } \\
\left.(2 \%)^{*}\right)(\mathrm{kg} / \mathrm{ha})\end{array}$ & $\begin{array}{l}\text { P2O5 content in } \\
\text { dry biomass } \\
(0.25 \%)^{*}(\mathrm{~kg} / \mathrm{ha})\end{array}$ & $\begin{array}{l}\mathrm{K} 2 \mathrm{O} \text { content in } \\
\text { dry biomass } \\
(4 \%)^{*)}(\mathrm{kg} / \mathrm{ha})\end{array}$ & $\begin{array}{l}\text { Value of loss of } \\
\text { urea with urea } \\
\text { price IDR } \\
2,400 / \mathrm{kg} \text { (IDR) }\end{array}$ & $\begin{array}{c}\text { Lost value } \\
\text { of SP36 at } \\
\text { the price of } \\
\text { SP36 IDR. } \\
3,000 / \mathrm{kg} \\
\text { (IDR) }\end{array}$ & $\begin{array}{c}\text { The value } \\
\text { of } \mathrm{KCl} \text { loss } \\
\text { with } \mathrm{KCl} \\
\text { price of } \\
\text { IDR } \\
3,600 / \mathrm{kg} \\
\text { (IDR) }\end{array}$ & $\begin{array}{c}\text { Cost of } \\
\text { Loss of hara } \\
\text { elements } \\
\text { (IDR } \\
\text { /ha/year) }\end{array}$ \\
\hline 1 & 0 & 37 & 5 & 55 & 157,440 & 31,020 & 462,348 & 650,808 \\
\hline 2 & 0 & 51 & 7 & 89 & 253,200 & 50,670 & 745,956 & $1,049,826$ \\
\hline 3 & 0 & 86 & 9 & 182 & 450,720 & 97,020 & $1,389,996$ & $1,937,736$ \\
\hline 4 & 0 & 138 & 16 & 279 & 867,120 & 153,690 & $2,252,196$ & $3,273,006$ \\
\hline 5 & 0 & 151 & 19 & 258 & 920,400 & 166,950 & $2,093,652$ & $3,181,002$ \\
\hline
\end{tabular}

Source: [11]

\subsection{The Total Economic Value}

The results showed that the total income from land that had been done vegetative conservation for five years was IDR $89,078,368$ ha-1, while from land that had never done conservation; it was IDR 30,397,617 ha-1. Where the expenditure for conservation for five years is IDR $38,967,230$ ha-1, while the cost incurred by farmers for non-conserved land is IDR 10,320,000 ha- 1 . Thus, the total gross margin for land with a vegetative conservation system for five years is IDR 50,111,138 ha-1 and IDR 20,077,617 ha-1 without conservation (Table 4). 
Table 5. The Gross Margin Analysis of Conserved and Unconserved Land

\begin{tabular}{|c|c|c|c|c|c|c|c|}
\hline \multirow[t]{3}{*}{ Cultivation Year } & \multicolumn{7}{|c|}{ Conserved } \\
\hline & \multicolumn{3}{|c|}{ Revenue (IDR) } & \multicolumn{3}{|c|}{ Cost (IDR) } & \multirow[t]{2}{*}{ Gross margin } \\
\hline & Biomass & Food crops & TRK & Biomass & Food crops & TCK & \\
\hline 1 & $4,386,792$ & $7,916,666$ & $12,303,458$ & $4,825,529$ & $2,160,000$ & $6,985,529$ & $5,317,930$ \\
\hline 2 & $7,058,562$ & $6,081,243$ & $13,139,805$ & $5,304,806$ & $2,160,000$ & $7,464,806$ & $5,674,999$ \\
\hline 3 & $13,014,593$ & $4,601,905$ & $17,616,498$ & $8,341,748$ & $2,070,000$ & $10,411,748$ & $7,204,750$ \\
\hline 4 & $21,293,204$ & $2,634,114$ & $23,927,317$ & $10,165,292$ & $2,010,000$ & $12,175,292$ & $11,752,026$ \\
\hline 5 & $19,891,706$ & $2,199,585$ & $22,091,291$ & 9,857 & $1,920,000$ & $1,929,857$ & $20,161,434$ \\
\hline Total & $65,644,856$ & $23,433,513$ & $89,078,368$ & $28,647,230$ & $10,320,000$ & $38,967,230$ & $50,111,138$ \\
\hline \multicolumn{8}{|l|}{ Unconserved } \\
\hline 1 & & $9,066,666$ & $9,066,666$ & & $2,160,000$ & $2,160,000$ & $6,906,666$ \\
\hline 2 & & $8,733,333$ & $8,733,333$ & & $2,160,000$ & $2,160,000$ & $6,573,333$ \\
\hline 3 & & $6,466,667$ & $6,466,667$ & & $2,070,000$ & $2,070,000$ & $4,396,667$ \\
\hline 4 & & $4,430,000$ & $4,430,000$ & & $2,010,000$ & $2,010,000$ & $2,420,000$ \\
\hline 5 & & $1,700,952$ & $1,700,952$ & & $1,920,000$ & $1,920,000$ & - 219,048 \\
\hline Total & & $30,397,617$ & $30,397,617$ & & $10,320,000$ & $10,320,000$ & $20,077,617$ \\
\hline
\end{tabular}


Considering the increasingly widespread and rapid rate of degradation of agricultural land, and the weak implementation of soil conservation in East Nusa Tenggara, especially Timor Island, it is necessary to immediately make effective breakthrough efforts to save agricultural land. Soil conservation efforts must lead to the creation of a sustainable agricultural system that is supported by technology and is able to improve people's welfare and conserve land resources and the environment.

Based on the results of the study[13] explained that agricultural land with a slope of $>25 \%$ must be made with an inward sloping bench terrace conservation technique equipped with drainage channels and groundwater traps, equipped with a main drainage channel planted with Paspalum notatum grass and a terrace height of approx. $70 \mathrm{~cm}$ while on slopes $>45 \%$, it is necessary to strive for the presence of dense undergrowth.

The results showed that the relationship between the cultivation system and income from land that was conserved during the five years of exploitation showed an increasing trend and formed an increasing regression line with the equation $y=$ $4 \mathrm{E}+06 \mathrm{e} 0.146 \mathrm{x}$, while on land that was not conserved it showed a decreasing trend and form a linear regression where the equation $y=-1 \mathrm{E}+06 \mathrm{x}+6 \mathrm{E}+06$ (Figure 2)

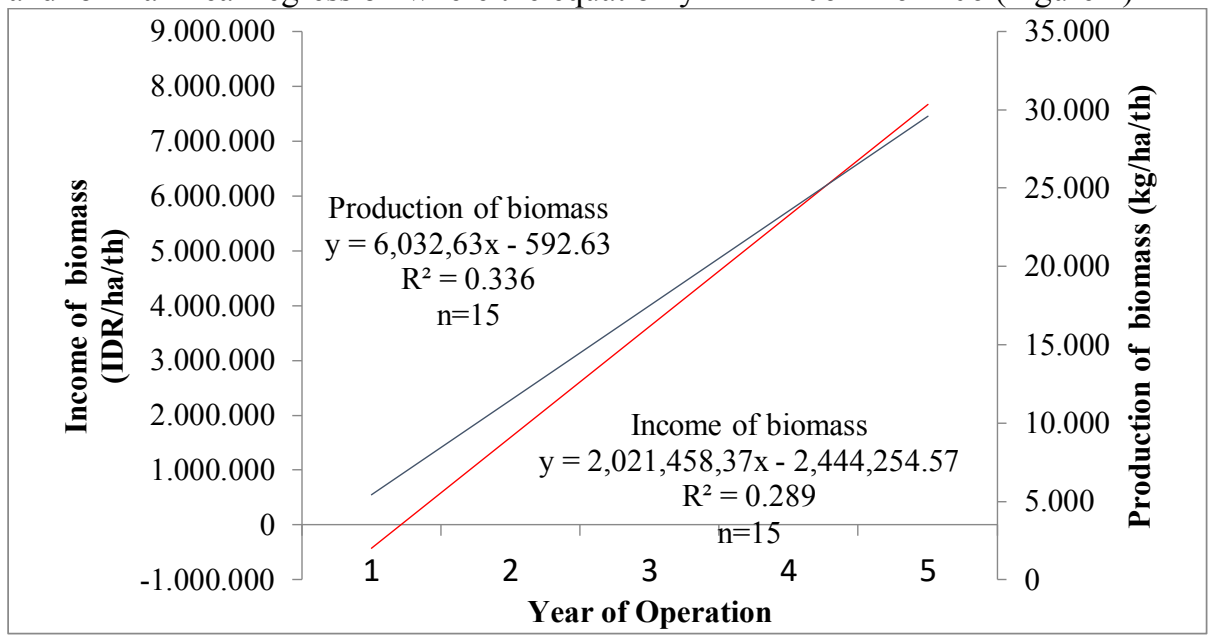

Fig. 2. The Regressive Equation for Hegde Row Biomass Production and Revenue on Land Where Soil Conservation Efforts were Conducted for Five Years

The existence of a hedge row that incorporates components of forage plants into field farming is a form of multiple cropping because there are two or more types of plants on the same land within one year [15]. It has been explained earlier that the existence of a hedge row has a better effect on the preservation of natural resources than single plantations. Meanwhile, when assessed from an economic point of view, the existence of a hedge row provides added economic value from the feed crops produced, but reduces the value of corn production until the fourth year due to a reduction in the portion of land area [16]. 


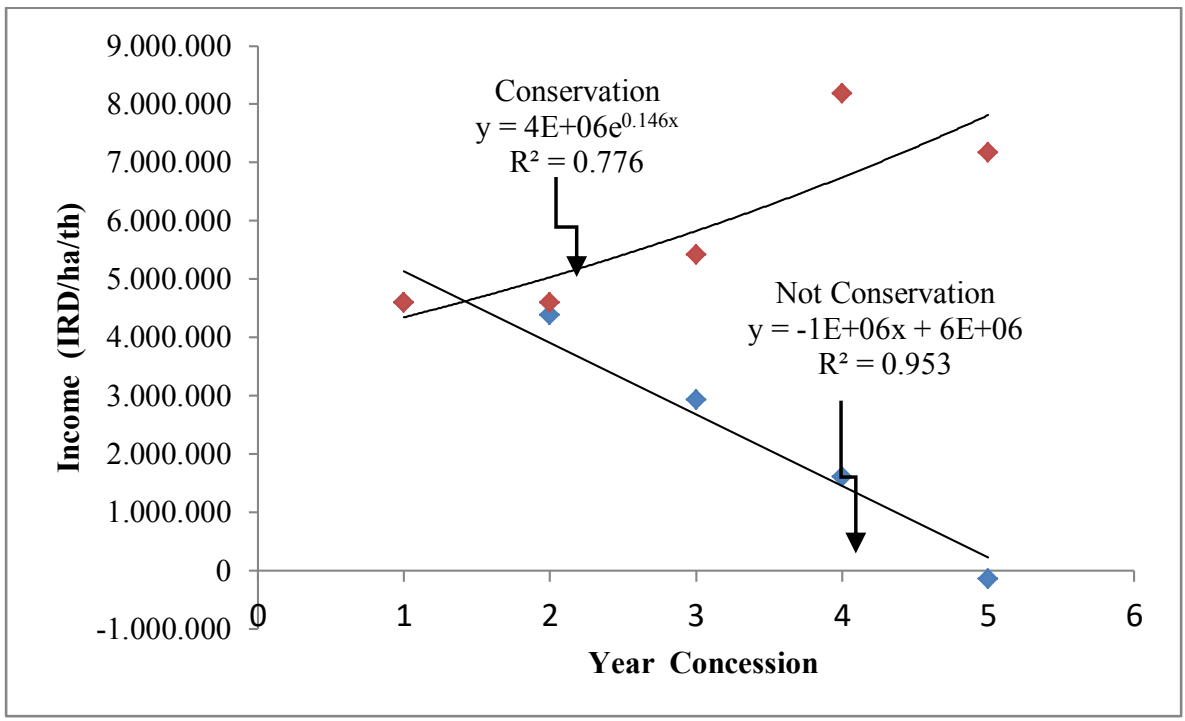

Fig. 3. The Regression Equation for the Effect of Cultivation Time on Revenue from Land where Vegetative Conservation Efforts Have and Have not been done

Biomass hedge row as a supplier of organic matter. The production of wet biomass in the fourth - fifth year is 25 tons or equivalent to 6 tons of dry biomass. If it is assumed that the biomass content of elephant grass is $2 \% \mathrm{~N}, 0.25 \% \mathrm{P} 2 \mathrm{O} 5$ and $4 \% \mathrm{~K} 2 \mathrm{O}[11]$ then the resulting biomass will contain $120 \mathrm{~kg} \mathrm{~N}, 15 \mathrm{P} 2 \mathrm{O} 5$ and 240 $\mathrm{kg} \mathrm{K} 2 \mathrm{O}$.

Hedge row biomass has the potential to provide cattle feed. If it is assumed that the biomass that can be consumed by livestock is $50 \%$, the potential supply of feed from vegetative conservation is 25 tons per year. [4] said that the feed requirement of Bali cattle is 10-20 of body weight per day. If it is assumed that the need for feed for cattle weighing $200 \mathrm{~kg}$ per head, the consumption is $20-30 \mathrm{~kg}$ per day. [14] For a fattening business for 6 months (one fattening period) the need for food consumption for $1 \mathrm{cow}$ is $3,750-5,350 \mathrm{~kg}$ per head per $5-7$ months. The potential supply of feed is 25 tons per year, then the potential for supplying feed for $5-7$ months is 12.5 tons. Thus the pattern offered can supply the feed needs of about 2-3 cows per 5 - 7 months of fattening. or 4-6 heads per year [15]

Efforts to make grass as a hedge is a vegetative conservation technique that can be accepted by farmers, because in addition to controlling soil erosion, it can also solve the problem of lack of feed for ruminants kept by farmers. [6]. [3] said that the carrying capacity of terrace reinforcing plants on bench terraces ranged from 21 59 sheep ha-1 year-1. The carrying capacity includes food crop waste grown in the processing field which can be given to livestock. The contribution of core strengthening plants to feed supply ranges from $50-60 \%$.

Vegetative soil conservation techniques include: reforestation, agroforestry, including alley cropping, strip cropping, grass strips, rows of crop residues, cover crop, the application of cropping patterns including crop rotation, intercropping, and relay cropping. Reforestation is carried out on critical lands caused by erosion, 
landslides, and human activities such as mining, shifting cultivation, and logging [13].

The existence of a hedge row that includes components of forage crops into field farming is a form of multiple cropping because there are two or more types of plants on the same land within one year. It has been explained earlier that the existence of a hedge row has a better effect on the preservation of natural resources than single plantations. Meanwhile, when assessed from an economic perspective, the existence of a hedge row provides added economic value from the feed crops produced, but reduces the value of corn production until the fourth year due to a reduction in the portion of land area[16].

\section{Conclusion and Suggestions}

\subsection{Conclusion}

The results of this study can be concluded as follows; By doing vegetative conservation, it can generate additional money of IDR 89,078,368, which can be obtained from fodder plants planted as hedges for five years of cultivation, while land where farmers do not carry out conservation does not generate additional money. For food crops that are gardened together with forage plants in the same land unit as aisle plants, the amount is IDR 23,433,513, while on land where the farmers do not carry out conservation, it is IDR 30,397617. The total gross margin on land with vegetative conservation for five years of cultivation is IDR 50,111,138 ha- 1 and for land that is not conserved, IDR 20,077,167 ha-1.

\subsection{Suggestions}

Vegetative conservation can be optimized by: (a) creating a cropping system where food crops are planted in alleys between rows of hedgerows (b). making a strip cropping system, the system is almost the same as alley planting but the hedge is grass, its function is to resist soil erosion. C. Prepare cover crops, where plants are planted alone or together with the main crop. (d) integrating crops and livestock, (c) changing the habit of not fertilizing the land to fertilizing with manure, and (d) not burning food crop biomass when preparing the land.

Conflict of Interest. The authors declare that there are no conflicts of interest regarding the publication of this paper

Acknowledgements. The author is very grateful to the Head of the Assessment Institute for Agricultural Technology East Nusa Tenggara and Development Center, the Center for Agricultural Research and Development who has provided funding for this research through the East Nusa Tenggara AIAT Fund for Fiscal Year 2017. The author also states that this research has the support of all the authors listed as the main contributors until this scientific paper has been published. 


\section{References}

1. BPS NTT, Ntt.Bps.Go.Id (2018).

2. A. Suryana and A. Agustian, Anal. Kebijak. Pertan. 12, 143 (2016).

3. S. Sukmana and H. Suwardjo, Indones. Agric. Res. Dev. J. 13, (1991).

4. R. B. Wirdahayati, in Dukungan Teknol. Terhadap Pengemb. Sapi Potong Di Nusa Tenggara Timur (Balai Besar Pengkajian dan Pengembangan Teknologi Pertanian (BBP2TP), Bogor, 2007).

5. Y. Arifien, S. Anggarawati, and D. B. Wibaningwati, in IOP Conf. Ser. Earth Environ. Sci. (2021).

6. Y. Soelaeman, Bul. Peternak. (1999).

7. Haryati., A. Rachman, Y. Soelaeman, T. Prasetyo, and A. Abdurachman, in Proceeding Work. Conserv. Agric. Syst. Jratunselena Brantas River Basins (Badan Libang Pertanian, 1991).

8. I. N. Duwijana and I. B. Aribawa, Bul. Teknol. Dan Inf. Pertan. 12, 116 (2014).

9. Kotler dan Keller, Manajemen Pemasaran, Edisi 12, Jilid 1, PT.Indeks,. Jakarta. (2017).

10. K. Rengsirikul, A. Kanjanakuha, Y. Ishii, K. Kangvansaichol, P. Sripichitt, V. Punsuvon, P. Vaithanomsat, G. Nakamanee, and S. Tudsri, Grassl. Sci. 57, (2011).

11. Manglayang Farm Online, Manglayang (2005).

12. N. Saptana and N. Ilham, Anal. Kebijak. Pertan. (2018).

13. A. Dariah, U. Haryati, and T. Budhyastoro, in Teknol. Konserv. Tanah Pada Lahan Kering Berlereng (Pusat Penelitian dan Penelitian Tanah dan Agroklimat, Bogor, 2004), pp. 107-131.

14. E. W. Riptanti, M. Masyhuri, I. Irham, and A. Suryantini, AIMS Agric. Food 5, (2020).

15. I. Danasari, H. Harianto, and A. Falatehan, J. Ekon. Pertan. Dan Agribisnis (2020).

16. W. Widjiati, T. Sardjito, and N. Harijani, J. Layanan Masy. (Journal Public Serv. (2017). 